hinted at by the spectrograph, that the chemical interaction of germanium and cadmium is of significance in consideration of electrolytic zinc cell problems. Analysis of variance showed that the interaction of germanium and cadmium was of such statistical importance that it must be regarded as a factor in the variation of cell current efficiencies due to other than random causes.

Significance of Difference: To obtain further evidence of the relationship between germanium and cadmium, the solutions on the 0.0000 and the 1.0000 $\mathrm{g}$ per liter levels of cadmium concentrations were investigated in a somewhat different manner. A test for the significance of the difference of the means of these two groups of data was made. The methods of "Student" and Fisher" were followed.

Such calculations indicated that a statistically significant difference existed between mean values of the data. The primary assignable cause of that difference was variation of the cadmium concentration. Such random errors as may have been introduced by slight fluctuations of other variables were minimized by the method of calculation.

\section{Summary and Conclusions}

The significance of difference and analysis of variance tests as performed on the above data substantiate the claim that definite interaction exists in the zinc cell between cadmium and germanium concentrations. Germanium alone, within normal operating limits, does not cause large current efficiency losses. Rather, this research indicates that the adverse effects of germanium are notably enhanced by the presence of cadmium, and that the presence of germanium in leach solutions of the commercial zinc sulphate type precludes the complete removal of cadmium from them. This leads to further ques- tions, as yet unsettled. What, if any, are the effects of the interactions of other impurities such as arsenic, antimony, bismuth, and lead, in the minute quantities found present after purification by present methods? How is the cell overvoltage affected by these interactions? What is the physical-chemical answer to the existence of such interactions? These are now being investigated in this laboratory.

While the answers to these questions are of academic interest, the commercial picture remains the same. Regardless of the nature of the interactions, germanium and cadmium must be removed in sufficient quantity before efficient electrowinning of germanium-tainted ores can be accomplished. It does not matter to the zinc producer whether germanium causes efficiency losses directly, or whether germanium and cadmium cause efficiency losses. In either event, the difficulty is there and a remedy must be found.

\section{References}

${ }^{1}$ U. C. Tainton and E. T. Clayton: Amer. Electrochem. Soc. (1930) 5\%, p. 279.

${ }^{2}$ D. M. Liddell: Handbook of Non-ferrous Metallurgy. (1945) McGraw-Hill Book Co.

${ }^{3}$ J. L. Bray: Non-ferrous Production Metallurgy. (1941) John Wiley and Sons.

${ }^{4}$ W. A. Koehler: Principles and Applications of Electrochemistry. Vol. II (1944) John Wiley and Sons.

${ }^{5}$ S. W. Ross: Trans. AIME (1949) 185, p. 205; JourNAL of Metals (March 1949).

${ }^{6}$ R. A. Fisher and F. Yates: Statistical Tables for Biological, Agricultural and Medical Research. (1938) Oliver and Boyd.

${ }^{7}$ H. A. Freeman: Industrial Statistics. (1942) John Wiley and Sons.

8 "Student", pseudonym of W. S. Gossett: Biometrika (1908) 6.

${ }^{\circledR}$ R. A. Fisher: Metron (1925) 5.

Technical Note

\title{
Deformation Texture of Cold-Drawn Copper Wire
}

\author{
by Walter R. Hibbard, Jr.
}

$\mathbf{B}^{A}$ $A C K O F E N$ ' reported recently that "the deformation texture of cold-drawn OFHC copper wire, after a reduction in area of 97.3 pct, may still be described as a composite of [111] and [100] directions aligned parallel to the wire axis." In the introduction, he indicated that this was in contrast to the work of Hibbard, ${ }^{2}$ who reported a single [111] texture after a reduction of 96.4 pct. Unfortunately Backofen stated that this was a reduction in area when actually it was a reduction in diameter, as is clearly stated in the reference. Moreover, the results of Backofen are in complete agreement with the results of Hibbard. Backofen's 97.3 pct reduction in area is an 83.3 pct reduction in diameter, after which he found a double [111] and [100] texture with the former predominating. Similarly, Hibbard, ${ }^{2}$ after an 86 pct reduction in diameter found a double [111] and [100] texture with the former predom-

W. R. HIBBARD, JR., Member AIME, is Associate Professor of Metallurgy, Yale University, New Haven, Conn.

TN 75E. Manuscript, March 12, 1951. inating. Hibbard, however, when he drew the wire further to 96.4 pct reduction in diameter, found primarily a single [111] texture as illustrated by Fig. 2 of ref. 3. Here also, Hibbard ${ }^{3}$ reported evidences of the [100] recrystallization texture found by Backofen. It might also be pointed out that Backofen not only drew his wire 97.3 pct reduction in area but also etched them over 99 pct reduction in area from 0.125 to 0.01 in. diam. Hibbard's wires were drawn directly to size.

In summary, the deformation texture of colddrawn copper wire still may be described as primarily a single [111] texture after a sufficient amount of drawing, such as 96.4 pct reduction in diameter. ${ }^{2,3}$

\section{References}

${ }^{1}$ W. A. Backofen: Journal of Metals (March 1951), Trans. AIME, p. 250.

${ }^{2}$ W. R. Hibbard, Jr.: Trans. AIME (1949) 185, p. 598; JouRnal of Metals (Sept. 1949).

${ }^{3}$ W. R. Hibbard, Jr.: Journal Inst. of Metals (London) (August 1950) p. 581. 